\title{
PENGARUH STRES KERJA TERHADAP KEPUASAN KERJA PEGAWAI DI KANTOR CABANG PT. PEGADAIAN (PERSERO)
}

\section{Sri Wahyu Utami*}

*Fakultas Ilmu Pendidikan, Universitas Negeri Jakarta

**Fakultas Ilmu Pendidikan, Universitas Negeri Jakarta

DOI: https://doi.org/10.21009/JPPP.021.11

Alamat Korespondensi:

sriwahyuutami2706@gmail.com

\begin{abstract}
This study aims to research determine the effect of job stress against job satisfaction employees in the branch offices of PT. Pegadaian (Persero). Variabel studied were job stress as the independent variable (X) and variable job satisfaction as the dependent variable (Y). The method used in this study is quantitative research. The sample in this study amounted to 31 respondents. Techniques used in the purposive sampling and quota sampling. The data analysis technique are used to test the hypothesis is a simple regression analysis using SPSS version 17.00. Based on the calculations, the $p$ value for the correlation of job stress and job satisfaction of 0.001 ( $p<0,05)$. Regression equation, $Y=116,144-0,656 X$ and the level of influence ( $R$ Square) of job stress on job satisfaction is 0.284 , which means that job stress affects job satisfaction by $28,4 \%$ and the remaining $71,6 \%$ is influenced by factors other than job stress. Therefore, Ho is rejected and Ha accepted so it can be concluded that there was a significant influence between job stress on job satisfaction of employees in branch offices PT. Pegadaian (Persero).
\end{abstract}

Keywords

job stress, job satisfaction, PT. Pegadaian (Persero)

\section{Pendahuluan}

Pegawai adalah makhluk sosial yang menjadi kekayaan utama bagi setiap perusahaan. Mereka ini menjadi perencana, pelaksana, dan pengendali yang selalu berperan aktif dalam mewujudkan tujuan perusahaan. Selain mereka mewujudkan tujuan perusahaan, mereka pun memiliki tujuan, pemikiran, perasaan, dan keinginan yang dapat mempengaruhi sikapnya terhadap pekerjaannya. Anoraga (2009) mengungkapkan bahwa dahulu orang-orang beranggapan bahwa satu-satunya perangsang (incentive) untuk bekerja hanyalah uang atau perasaan takut untuk menganggur. Kenyataannya menunjukkan bahwa orang mau bekerja bukan hanya mencari dan mendapatkan upah saja (unsur ekonomis) akan tetapi dengan bekerja mereka mengharapkan akan mendapatkan kepuasan kerja.

Kepuasan kerja akan mempengaruhi produktivitas yang sangat diharapkan perusahaan dan perusahaan pun memang membutuhkan tenaga kerja yang produktif untuk dapat menunjang kehidupan perusahaan. Umam (2010) mengemukakan produktivitas dapat dinaikkan dengan menaikkan kepuasan kerja. Kepuasan kerja merupakan akibat dari produktivitas atau sebaliknya. Produktivitas yang tinggi akan menyebabkan peningkatan kepuasan kerja hanya jika karyawan mempersepsikan bahwa apa yang telah dicapai perusahaan sesuai dengan apa yang diterima, serta diasosiasikan dengan performa kerja yang unggul. 
Howel dan Dipboye, 1986 (dalam Munandar, 2001) memandang kepuasan kerja sebagai hasil keseluruhan dari derajat rasa suka atau tidak sukanya tenaga kerja terhadap berbagai aspek dari pekerjaannya. Dengan kata lain kepuasan kerja mencerminkan sikap tenaga kerja dengan pekerjaannya. Ada banyak faktor yang mempengaruhi kepuasan kerja sehingga tidak semua orang yang bekerja merasakan kepuasan kerja. Jika faktor-faktor yang mempengaruhi kepuasan kerja terpenuhi maka dapat mengakibatkan perasaan kepuasan kerja. Tetapi jika faktor tersebut tidak dapat terpenuhi maka para pegawai akan merasakan ketidakpuasan kerja.

Munandar (2001) mengemukakan faktor-faktor yang mempengaruhi kepuasan kerja antara lain: ciri-ciri intrinsik, gaji yang dirasakan adil, penyeliaan, rekan kerja, dan kondisi kerja yang menunjang. Ketidakpuasan kerja dapat dirasakan para pegawai tidak hanya karena faktor tersebut tidak dapat terpenuhi tetapi kondisi stres kerja pun dapat mengakibatkan ketidakpuasan kerja.

Wahjono (2010) mengemukakan bahwa stres dapat menyebabkan ketidakpuasan, terutama ketidakpuasan yang berkaitan dengan pekerjaan. Stres yang dialami dan kepuasan kerja yang didambakan adalah dua kondisi yang bukan saja berkaitan, tetapi sekaligus antagonis. Karena memang terjadi situasi kompleks antara stres manusia, pekerjaan dan kepuasan.

Robbins (Wahjono, 2010) mengemukakan stres merupakan kondisi dinamik yang di dalamnya individu menghadapi peluang, kendala, atau tuntutan yang terkait dengan apa yang sangat diinginkannya dan yang hasilnya dipersepsikan sebagai tidak pasti tetapi penting. Setiap aspek di pekerjaan dapat menjadi pembangkit stres. Faktor-faktor di pekerjaan yang berdasarkan penelitian dapat menimbulkan stres dapat dikelompokkan ke dalam lima kategori besar, yaitu faktor-faktor intrinsik dalam pekerjaan, peran dalam organisasi, pengembangan karier, hubungan dalam pekerjaan, serta struktur dan iklim organisasi (Hurrel, dkk. 1988; Munandar, 2001).

Dalam konteks perilaku organisasi, stres dapat dilihat dari sisi negatif maupun sisi positif. Quick dan Quick (1984; Waluyo, 2009) mengkategorikan jenis stres menjadi dua, yaitu eustress dan distress. Eustress, yaitu hasil dari respon terhadap stres yang bersifat sehat, positif, dan konstruktif (bersifat membangun). Sedangkan distress, yaitu hasil dari respon terhadap stres yang bersifat tidak sehat, negatif, dan destruktif (bersifat merusak).

Berbagai penelitian telah banyak mengemukakan bahwa stres kerja memiliki hubungan yang negatif terhadap kepuasan kerja. Hal ini berarti penurunan tingkat stres kerja memiliki hubungan terhadap naiknya tingkat kepuasan kerja. Walaupun demikian, pengkategorian jenis stres menjadi eustress dan distress dapat mengemukakan bahwa stres dapat memungkinkan hasil korelasi yang positif antara stres kerja dengan kepuasan kerja. Ditambah lagi hasil korelasi dari penelitian Anitawidanti (2010) yang menunjukkan bahwa variabel stres kerja memiliki hubungan positif dengan variabel kepuasan kerja, yang berarti bahwa jika stres kerja meningkat maka kepuasan kerja juga meningkat. Stres kerja dalam penelitian yang dilakukan oleh Anitawidanti lebih mengarah pada eustress yaitu stres positif yang diperlukan untuk menghasilkan prestasi yang tinggi. Hal tersebut dapat menimbulkan asumsi bahwa perusahaan tidak hanya menciptakan keadaan stres yang menekan tetapi ada pula penciptaan keadaan stres yang menyenangkan.

Hasil penelitian (Munandar, 2001) menunjukkan adanya hubungan berbentuk-U terbalik antara stres dan unjuk-kerja pekerjaan, tampak bahwa stres tingkat rendah dan tingkat tinggi dua-duanya menghasilkan unjuk-kerja pekerjaan yang rendah. Dapat dikatakan, situasi stres yang berada di titik optimal merupakan eustress karena pekerja merasakan situasi tersebut ialah situasi yang menantang. Hal demikian membuat pekerja merasakan kepuasan kerja. Sedangkan situasi stres yang berada di tingkat rendah maupun tingkat tinggi membuat pekerja merasakan ketidakpuasan kerja.

Tinggi dan rendahnya tingkat stres dipengaruhi oleh situasi kerja. Tiap bagian pekerjaan dalam suatu perusahaan memungkinkan perbedaan tingkat stres karena berbedanya situasi kerja yang dirasakan. Satu bagian pekerjaan pun dapat mengalami perbedaan tingkat stres dari waktu ke waktu dan ditambah pula bila ada perubahan organisasi dalam pekerjaan tersebut. Cara orang melihat atau menanggapi perubahan, bukan untuk 
mengubah dirinya sendiri, adalah sumber stres (Schutz \& Schultz, 2010).

Perubahan organisasi dapat dirasakan oleh para pegawai yang bekerja di PT. Pegadaian (Persero). Hal tersebut dikarenakan berubahnya status badan hukum melalui Peraturan Pemerintah Nomor 51 yang diterbitkan pada 13 Desember 2011 yaitu dari Perum Pegadaian menjadi PT Pegadaian (Persero) (warta pegadaian edisi 160). Seluruh elemen dalam perusahaan akan bersama-sama menjalani rangkaian perjalanan dalam perubahan ini untuk menuju ke arah yang lebih baik. Perubahan ini juga termasuk di jajaran frontliner Pegadaian, yang lebih professional, serta berorientasi kepada pelayanan nasabah (warta Pegadaian edisi 163).

Front Liner atau garis depan adalah istilah bagi mereka yang bekerja langsung berhadapan dengan para pelanggan pengguna produk dari sebuah perusahaan. Di PT. Pegadaian (Persero), petugas garis depan terdiri dari para teller (sekarang istilahnya PAP, yaitu Pendukung Administrasi dan Pembayaran) dan pengeluar barang. Seorang front liner sekarang ini sudah harus meninggalkan sesuatu yang biasa-biasa saja dan harus menjadi luar biasa karena hal luar biasa yang dimiliki oleh seorang front liner inilah yang akan menciptakan memorable experience bagi pelanggan mereka. Hanya front liners yang mempunyai kemampuan dan keterampilan yang baik yang dapat bergabung dengan Pegadaian. Dengan kata lain, yang terbaik dikelasnya yang dapat menjadi pasukan terdepan perusahaan. Tuntutan tersebut dapat menjadi stressor bagi para pegawai frontliners di PT Pegadaian (Persero).

Pegawai front liner bekerja bersama dengan penaksir, penyimpan, pemegang gudang, security dan pemasar di kantor cabang/UPC dalam melayani nasabah. Banyaknya rekan kerja tersebut tidak sama di semua kantor cabang yaitu sesuai dengan besarnya jumlah omset dan kantor cabang. Ada beberapa kantor cabang yang pegawainya hanya terdiri dari dua orang yaitu security dan PAP yang merangkap sebagai penaksir.

Banyaknya rekan kerja dapat mengurangi tingkat stres yang dirasakan, dengan syarat jika terjadi hubungan yang harmonis dengan rekan kerja yang lain dan rasa solidaritas yang tinggi. Rekan kerja dapat mengurangi beban ataupun dapat menyelesaikan masalah yang ada secara bersama-sama karena para pegawai di kantor cabang lebih rentan mendapatkan masalah dari pihak luar. Mereka lebih rentan mendapatkan masalah dari pihak luar karena merekalah yang berhadapan langsung dengan para nasabah. Terkadang ada nasabah yang kurang kooperatif sehingga dapat menimbulkan masalah.

Kantor cabang yang terdiri dari dua pegawai memungkinkan tingkat stres yang lebih tinggi dibandingkan kantor cabang yang memiliki banyak pegawai. Hal tersebut dikarenakan jika terdapat masalah maka hanya PAP sendirilah yang menangani masalah tersebut. Perkerjaan yang terisolasi, dimana tenaga kerja tidak dapat berbicara dengan tenaga kerja lain selama jam kerja dan bekerja sendiri sepanjang hari yang dirasakan tersebut ditambah dengan beban kerja yang harus ia hadapi sendiri dapat menjadi sumber stres kerja. Hal tersebut dapat membuat semakin bertambahnya potensi stres kerja para pegawai PT Pegadaian (Persero) di kantor cabang.

Oleh karena itu peneliti ingin meneliti pengaruh stres kerja terhadap kepuasan kerja pegawai di kantor cabang PT Pegadaian (Persero).

Berdasarkan uraian di atas maka dapat dikemukakan rumusan masalah penelitian ini adalah "Pengaruh stres kerja terhadap kepuasan kerja pegawai di kantor cabang PT. Pegadaian (Persero)."

Hipotesis yang digunakan dalam penelitian ini yaitu Ha: terdapat pengaruh stres kerja terhadap kepuasan kerja pegawai di kantor cabang PT Pegadaian (Persero). Sedangkan hipotesisnya Null yaitu Ho: tidak terdapat pengaruh stres kerja terhadap kepuasan kerja pegawai di kantor cabang PT Pegadaian (Persero).

\section{Metode Penelitian}

Penelitian ini termasuk ke dalam jenis penelitian survei yang berupa penelitian korelasi. Berdasarkan waktu pengumpulannya data dalam penelitian ini termasuk data kerat lintang (cross section). Hasan (2006) menjelaskan bahwa data kerat lintang adalah data yang terkumpul pada suatu waktu tertentu untuk memberikan gambaran perkembangan suatu kegiatan atau keadaan pada waktu itu.

Populasi dalam penelitian ini ialah pegawai kantor cabang di kantor wilayah IX PT Pegadaian 
(Persero). Unit Pelayanan Cabang (UPC) yang ditentukan untuk menjadi sampel dalam penelitian ini ialah UPC Tanjung Priok dengan teknik sampling yaitu teknik purposive sampling dan kuota sampling.

Variabel-variabel dalam penelitian ini diukur dengan menggunakan dua instrumen yaitu instrumen untuk mengukur variabel stres kerja dan instrumen untuk mengukur variabel kepuasan kerja. Instrumen untuk mengukur variabel stres kerja peneliti susun berdasarkan faktor-faktor stres kerja yang mengacu pada Hurrell, dkk. (dalam Munandar, 2001) dan Coope (dalam Umam, 2010). Sedangkan instrumen untuk mengukur variabel kepuasan kerja peneliti susun berdasarkan faktor-faktor kepuasan kerja yang dijelaskan oleh Munandar (2001).
Teknik analisis data yang digunakan dalam penelitian ini ialah analisis regresi linear sederhana. Analisis regresi digunakan untuk memprediksi pengaruh variabel bebas terhadap variabel terikat.

\section{Hasil Penelitian dan Diskusi}

Dari perhitungan data variabel kepuasan kerja dan stres kerja diperoleh nilai rata-rata dan nilai simpangan baku tiap variabel. Adapun nilai tersebut yaitu: nilai rata-rata kepuasan kerja sebesar 71,35 dan nilai rata-rata stres kerja yaitu sebesar 68,29. Nilai standar deviasi atau simpangan baku kepuasan kerja sebesar 8,114 sedangkan nilai standar deviasi stres kerja sebesar 6,589 . Dengan mengetahui besarnya mean dan standar deviasi maka dapat diketahui tingkatan kepuasan kerja dan stres kerja sebagai berikut:

Tabel 1. Tingkat Kepuasan Kerja

\begin{tabular}{cccccc}
\hline Tingkatan & Sangat Tidak Puas & Tidak Puas & Netral & Puas & Sangat Puas \\
\hline Responden & 3 & 9 & 2 & 14 & 3 \\
\hline Persentase & $10 \%$ & $29 \%$ & $6 \%$ & $45 \%$ & $10 \%$ \\
\hline
\end{tabular}

Tabel 2. Tingkat Stres Kerja

\begin{tabular}{cccccc}
\hline Tingkatan & Sangat Tidak Puas & Tidak Puas & Netral & Puas & Sangat Puas \\
\hline Responden & 5 & 12 & 0 & 10 & 4 \\
\hline Persentase & $16 \%$ & $39 \%$ & $0 \%$ & $32 \%$ & $13 \%$ \\
\hline
\end{tabular}

Dari tabel di atas dapat diketahui bahwa tingkatan kepuasan kerja dari responden dalam penelitian ini didominasi oleh responden yang merasakan kepuasan kerja yaitu sebesar $45 \%$ sedangkan responden yang paling sedikit yaitu responden dengan perasaan netral yaitu sebesar $6 \%$.

Untuk data stres kerja didominasi oleh responden yang tidak merasakan stres kerja yaitu sebesar 39. Sama seperti tingkatan kepuasan kerja, pada tingkatan stres kerja responden yang paling sedikit yaitu responden dengan perasaan netral yaitu sebesar $0 \%$ atau tidak ada responden.

Untuk mengetahui besarnya pengaruh stres kerja terhadap kepuasan kerja dapat dilihat pada tabel di bawah ini:

Tabel 3. Korelasi Stres Kerja dan Kepuasan Kerja

\begin{tabular}{cccc}
\hline & & $\begin{array}{c}\text { Kepuasan } \\
\text { Kerja }\end{array}$ & $\begin{array}{c}\text { Stres } \\
\text { Kerja }\end{array}$ \\
\hline Pearson & Kepuasan Kerja & 1 & $-0,533$ \\
\cline { 2 - 4 } Correlation & Stres Kerja & $-0,533$ & 1 \\
\hline \multirow{2}{*}{ Sig. (1-tailed) } & Kepuasan Kerja & 0 & 0,001 \\
\cline { 2 - 4 } & Stres Kerja & 0,001 & 0 \\
\hline
\end{tabular}


Berdasarkan hasil perhitungan di atas maka didapatkan koefisien korelasi variabel stres kerja dengan kepuasan kerja sebesar -0.533 dan sig. (1tailed) sebesar 0.001 . Nilai probabilitas atau sig. (1-tailed) sebesar 0.001 yaitu lebih kecil dari tingkat kesalahan (alpha) sebesar 0.05. Hal ini berarti Ho ditolak atau Ha diterima, maka dapat dikatakan bahwa terdapat pengaruh yang signifikan antara stres kerja terhadap kepuasan kerja pegawai di kantor cabang PT Pegadaian (Persero).

Koefisien korelasi variabel stres kerja terhadap kepuasan kerja sebesar -0.533. Arah korelasi yang negatif mengandung pengertian bahwa semakin rendah stres kerja maka semakin tinggi kepuasan kerja, sebaliknya semakin tinggi stres kerja maka semakin rendah kepuasan kerja. Jadi variabel kepuasan kerja dan stres kerja memiliki hubungan yang berlawanan (tidak searah). Hal ini pun dapat terlihat dari perbedaan tingkat kepuasan kerja maupun tingkat stres kerja responden. Untuk variabel kepuasan kerja di dominasi oleh responden yang merasakan kepuasan kerja sedangkan untuk variabel stres kerja di dominasi oleh responden yang tidak merasakan stres kerja. Hubungan yang tidak searah antara kepuasan kerja dan stres kerja mengindikasikan bahwa stres kerja dalam penelitian ini termasuk ke dalam distress.

Quick dan Quick (1984; Umam, 2010) menjelaskan bahwa distress ialah hasil dari respon terhadap stres yang bersifat tidak sehat, negatif, dan destruktif (bersifat merusak). Jadi jika tingkat stres kerja meningkat maka pegawai akan merasakan sifat stres yang semakin negatif dan merusak yang berdampak pada rasa ketidakpuasan kerja (tingkat kepuasan kerja semakin rendah).

Nilai korelasi sebesar -0.533 mengindikasikan bahwa hubungan antara variabel stres kerja dengan kepuasan kerja bersifat kuat. Hal ini mendukung hasil penelitian yang dijabarkan oleh Kreitner \& Kinicki (2010) bahwa hubungan antara stres yang dirasakan dengan kepuasan kerja bersifat negatif dan kuat.

Nilai koefisien determinansi (R Square) adalah 0.284 yang berarti pengaruh stres kerja terhadap perubahan kepuasan kerja sebesar $28.4 \%$ sedangkan $71.6 \%$ kepuasan kerja dipengaruhi oleh variabel lain selain stres kerja. Banyak variabel lain yang berkontribusi terhadap variabel kepuasan kerja. Kreitner \& Kinicki mencoba menjabarkan beberapa variabel yang berhubungan dengan kepuasan kerja yaitu motivasi, keterlibatan pekerjaan, komitmen organisasi, perilaku warga organisasi, absensi, keterlambatan, penarikan kognisi, omset, penyakit jantung, stres yang dirasakan, suara pro-serikat, kinerja, kepuasan hidup, dan kesehatan mental.

\section{Kesimpulan}

Penelitian ini mengkaji pengaruh antara stres kerja terhadap kepuasan kerja pegawai di kantor cabang PT. Pegadaian (Persero). Berdasarkan hasil penelitian, terdapat pengaruh yang signifikan antara stres kerja terhadap kepuasan kerja pegawai di kantor cabang PT. Pegadaian (Persero) dengan arah korelasi yang negatif. Dapat dikatakan bahwa stres kerja dalam penelitian ini termasuk ke dalam stres yang bersifat merusak (distres). Pengaruh stres kerja terhadap kepuasan kerja sebesar $28.4 \%$ sedangkan $71.6 \%$ kepuasan kerja dipengaruhi oleh variabel lain selain stres kerja.

\section{Daftar Pustaka}

Anitawidanti, H. (2010). Analisis hubungan antara stres kerja dengan kepuasan kerja karyawan berdasarkan gender Skripsi, Fakultas Ekonomi, Universitas Diponegoro, Semarang. Diakses pada tanggal 21 April 2012 dari http://eprints.undip.ac.id/22995/1/SKRIPS I_STRES_KERJA_VS_KEPUASAN_KE RJA.pdf.

Anoraga, P. (2009). Psikologi kerja (Cetakan Kelima). Jakarta: Rineka Cipta.

Hasan, I. (2006). Analisa data penelitian dengan statistik (Cetakan Kedua). Jakarta: Bumi Aksara.

Kinicki, A, \& Kreitner, Robert. (2005). Perilaku Organisasi, Edisi 5/Buku 2, (Erly Suandy, Penerjemah). Jakarta: Salemba Empat.

Munandar, A.S. (2001). Psikologi Industri dan Organisasi. Jakarta: UI-Press. 
Sri Wahyu Utami

Herwindo Hariwibowo

Siap-siap jadi perseroan terbatas. (2012). Warta Pegadaian Media Informasi dan Komunikasi, 160, 5.

Schultz, D.P. \& Schultz, Sydney Ellen. (2010). Psychology and Work Today (Tenth Ed.). New Jersey: Pearson.
Pengaruh Stres Kerja terhadap Kepuasan Kerja Pegawai di Kantor Cabang PT. Pegadaian (Persero)

Umam, K. (2010). Perilaku Organisasi. Bandung: Pustaka Setia.

Wahjono, S.I. (2010). Perilaku organisasi. Yogyakarta: Graha Ilmu.

Waluyo, M. (2009). Psikologi Teknik Industri. Yogyakarta: Graha Ilmu 